\title{
BAGAIMANA MENUMPAS TEROR?
}

Oleh Shohibul Anshor Siregar

Langsung saja masalah Revisi Undang-Undang nomor 15 tahun 2003 tentang Pemberantasan Tindak Pidana Terorisme (selanjutnya disebut saja RUU Teror) yang pembahasannya cukup lama tertunda menjadi salah satu pusat perhatian penting menyusul rentetan kejadian berkategori teror menjelang bulan Ramadhan tahun ini. Banyak orang menyorot Panitia Khusus (Pansus) DPR-RI dan menudingnya lamban serta tak memiliki niat baik.

Presiden Joko Widodo pun berkata: "Saya juga minta ke DPR dan kementerian terkait yang berhubungan dengan revisi UU Tindak Pidana Terorisme, yang sudah kita ajukan pada bulan Februari 2016 yang lalu, sudah dua tahun, untuk segera diselesaikan secepat-cepatnya dalam masa sidang berikut 18 Mei yang akan datang". Joko Widodo menyatakan itu melalui akun Twitter-nya (Tirto.id, 14 Mei 2018).

Tetapi Wakil Ketua MPR Hidayat Nur Wahid tak mau menerima tudingan itu. Malah ia meminta agar Presiden menegur saja dulu Menkumham, Yasonna H Laoly. Penyebab keterlambatan ada di sana. Wakil pemerintah dalam pembahasan RUU Teror (Yasonna $\mathrm{H}$ Laoly) itulah yang telah berulah, dan telah menyebabkan keterlambatan penyelesaian RUU Teror. Yasonna $H$ Laoly sudah beberapa kali berusaha menunda pembahasan RUU Teror. Ada surat resminya.

Tak hanya Hidayat Nur Wahid yang menyatakan kegusaran. Bahkan Ketua DPR RI Bambang Soesatyo, dan Ketua Pansus RUU Teror Romo Raden M. Syafi'i, juga angkat bicara, protes, bahwa masalah keterlambatan pembahasan RUU Teror justru ada pada pihak pemerintah.

Terasalah "ultimatum" Presiden Joko Widodo dengan nada mengancam akan mengeluarkan Peraturan Pemerintah Pengganti Undang-Undang (Perppu) itu menjadi aneh. Mengapa Menkuham Yasonna $\mathrm{H}$ Laoly menunda-nunda? Apa masalah sesungguhnya?

Saat berbicara pada ILC Selasa pekan lalu, Prof $\mathrm{Dr} H$ Dien Syamsuddin, dari Muhammadiyah yang kini juga sekaligus menjabat staf khusus Presiden, mengingatkan pemerintah agar tidak terlalu berambisi membuat regulasi yang kurang mempertimbangkan keserasian dengan konstitusi. Itu betul.

Pengalaman berkali-kali dikalahkan oleh gugatan rakyat pada sidang judicial review pada Mahkamah Konstitusi benar-benar menunjukkan ketak-matangan cara berfikir pemerintah. Betapa tidak, kini kita hidup pada alam demokrasi. Dunia pun juga memerhatikan kita. Regulasi seperti Perppu, yang dibuat terburu-buru, lazimnya akan menonjol emosionalitasnya dan akhirnya ketak-sempurnaannya sekaligus. Itu sangat terbuka untuk segera dibatalkan oleh Mahkamah Konstitusi, atas gugatan rakyat. 
Pemerintah juga perlu memupuk harga diri agar berwibawa. Tidak asal-asalan. Juga tidak mengesankan pentingnya kekuasaan eksekutif (diktatorship) di atas segalanya.

Saat ini kelihatannya sudah hampir semua pihak berpendapat koor akan perlunya pengesahan RUU Teror sesegera mungkin. Kata Kadiv Humas Mabes Polri Irjen Pol Setyo Wasisto, RUU Teror akan menjadi payung hukum bagi aparat untuk mencegah tindak pidana terorisme. Itu juga ditegaskan oleh Kapolri Jenderal Dr Muhammad Tito Karnavian pada ILC Selasa malam, pekan lalu.

Secara umum UU No 15 Tahun 2003 itu sifatnya dianggap reaktif belaka, dan bahkan ada yang menyebut lebih terbatas pada petingnya kesegeraan menyelesaikan kasus khusus pada teror bom Bali tempohari. Kelemahan UU itu misalnya, bahwa jika pelaku teror belum bertindak, sama sekali tidak bisa ditangkap. Sedangkan pihak berwajib berharap diberi kewenangan melakukan upaya preventif.

Konon tercatat bahwa Mantan Kepala Badan Nasional Penanggulangan Terorisme (BNPT), Ansyad Mbai, pada tahun 2010 yang lalu, adalah pihak yang pertamakali mendesak agar segera dilakukan revisi UU Nomor 15 Tahun 2003. la meminta dalam revisinya kelak terdapat pasal yang menjamin agar kepolisian dan lembaga berwenang lainnya dapat melakukan pencegahan terhadap kemungkinan terjadinya teror. Waktu itu wacana Mbai ditolak oleh sejumlah pihak.

Peneliti Wahid Foundation, Rumadi Ahmad, misalnya, melihat revisi UU 15/2003 terlalu berlebihan dan malah lebih mengisyaratkan negara yang ketakutan terhadap terorisme. Padahal semua tahu bahwa dengan UU yang ada Densus 88 Polri telah menjalankan tugasnya.

Desakan dari berbagai pihak sesungguhnya bukan tak diindahkan oleh Pansus RUU Teror. Ketua Pansus Romo H Raden M. Syafii menyatakan bahwa keterlambatan pembahasan merupakan keniscayaan karena pentingnya menyelenggarakan rangkaian Rapat Dengar Pendapat Umum (RDPU) dengan berbagai pihak untuk memeroleh masukan. Draf RUU Teror yang diusulkan pemerintah itu memang, singkatnya, tidak dapat ditelan bulat-bulat untuk disetujui. Banyak hal yang dipandang krusial.

Sebagaimana luas diketahui, RUU Teror versi pemerintah mereferensi Internal Security Act (ISA) Singapura dan Malaysia. Misalnya, pasal 73 ayat 1 ISA Malaysia ditegaskan bahwa polisi bisa menahan seseorang selama 60 (enam puluh hari) hari tanpa surat perintah dan bantuan hukum. Setelah itu Kementerian Dalam Negeri Malaysia bisa memperpanjang masa tahanan tanpa sidang sampai dengan dua tahun. Itu semua bisa dilakukan tanpa menyertakan bukti apa pun. Kalangan civil society di Indonesia pastilah sangat menolak ketentuan ini karena dipandang sangat riskan (kesewenangwenangan penguasa).

Institute for Criminal Justice Reform (ICJR) berpendapat jangankan 60 hari, bahkan waktu 30 hari pun sudah terlalu lama. ICJR membedakan antara penangkapan dan 
penahanan. Esensi keduanya sangat berbeda terutama jika merujuk pada pasal 1 angka 20 KUHAP (penangkapan adalah suatu tindakan penyidik berupa pengekangan sementara waktu kebebasan tersangka atau terdakwa). Meski pun waktu untuk proses mengejar dan menangkap itu tidak dibatasi oleh hukum acara, namun setelah seseorang atau sekelompok orang menjadi tersangka, masa penangkapan otomatis wajib dihitung untuk kemudian dilanjutkan dengan proses berikutnya.

Kiranya dapatlah difahami kekhawatiran ICJR bahwa penangkapan dalam jangka waktu lama selalu bisa berakibat fatal. Terbuka peluang besar pelanggaran HAM (apalagi dalam kasus terorisme). Memang jika suara orang-orang tertentu yang muncul pada media sosial disimak, bahkan pelaku teror itu bagi mereka terlalu beroleh kemewahan jika diberi HAM. Namun masalahnya apakah setiap orang yang dicurigai sebagai pelaku teror sudah benar-benar akan terbukti sebagai orang yang bertanggungjawab atas sebuah tindakan jahat yang dituduhkan? Ingatlah kasus Siyono.

Lagi pula, penahanan bersifat incommunicado (tanpa akses terhadap dunia luar) selalu membuka peluang besar untuk praktik yang bertentangan dengan HAM. Pelaksanaan penindakan (atas tindak pidana teror) dengan model ISA Singapura dan Malaysia itu tidak ideal dan tidak sesuai dengan nurani hukum dan keadilan di Indonesia. Jika akan diterapkan, tegas anggota DPR Nasir Djamil, diyakini berpotensi keluar dari jalur hukum, amat rawan digunakan oleh rezim untuk melakukan kesewenang-wenangan. Dengan amat tak suka ia membandingkan perlakuan Duterte dari Filipina. Apa pun alasan (bagi pemerintah) untuk mengadopsi ISA model Singapura dan Malaysia, banyak pihak serius menolaknya.

Selain itu masalah lain yang juga dipandang krusial ialah pelibatan TNI. Diketahui, sebetulnya sudah terdapat aturan landasannya pada UU TNI Pasal 7 ayat (2) tentang Operasi Militer Selain Perang (OMSP). Jika demikian hanya diperlukan sebuah mekanisme yang jelas dan terukur (akuntable) untuk menghindari penyalahgunaan wewenang.

Mengapa pelibatan TNI menuai kritik? Ada yang berpendapat (Koalisi Masyarakat Sipil untuk Reformasi Sektor Keamanan) bahwa pelibatan militer tidak perlu dalam revisi UU Teror. Kalangan ini berdalih bahwa UU yang diharapkan ialah UU yang dapat mengatur sebaik-baiknya dan secara terukur tata cara penegakan hukum. Hal yang perlu diatur adalah institusi-institusi terkait dengan penegakan hukum, bukan yang lain. Kalangan ini juga berpendapat bahwa TNI, berdasarkan UU Nomor 34 tahun 2004, tidak memiliki tugas utama sebagai penegak hukum, melainkan menjaga kedaulatan negara. UU telah mengatur keterlibatan TNI dalam tugas selain perang atas keputusan politik negara.

Meski pun akhirnya kini sudah seakan difahami bersama, bahwa mekanisme pelibatan TNI memang perlu diatur meslki landasannya sudah ada pada UU yang lain, namun 
Haris Azhar yang mantan Koordinator KontraS juga pernah mengeritik tak kurang kerasnya. Baginya masalah utama dari penanggulangan terorisme khususnya di Indonesia adalah pada sisi akuntabilitas, bukan seberapa penting melibatkan atau tidak melibatkan TNI.

Sekarang jika pada draft RUU Teror sudah muncul narasi [ayat (1)] yang menyatakan bahwa "Tugas TNI dalam mengatasi aksi terorisme merupakan bagian dari operasi militer selain perang" dan [ayat (2)] "Dalam mengatasi aksi terorisme sebagaimana dimaksud pada ayat (1) dilaksanakan sesuai denga tugas pokok dan fungsi TNI", serta [ayat (3)] "Ketentuan lebih lanjut mengenai pelaksanaan mengatasi aksi terorisme sebagaimana dimaksud pada ayat (1) diatur dengan Peraturan Presiden", apakah sudah cukup menjamin tak akan bermasalah dengan HAM?

Hal lain yang selama ini sangat lemah dalam pemahaman, wacana dan apalagi tindakan ialah sesuatu yang oleh Prof. Dr $\mathrm{H}$ Din Syamsuddin ditegaskan bahwa terorisme bukan hanya faktor ideologi (radikal) saja tetapi juga bisa menjadi sangat subur karena faktor-faktor rumit yang berkelindan dalam Poleksosbud. Indonesia yang selama ini memilih hanya percaya dan merasa hanya benar untuk fokus memerangi ideologi saja dan mengabaikan masalah politik, ekonomi, keadilan sosial dan budaya lokal atau politik global, ternyata tak mampu menyintuh akar masalah yang tidak ditemukan sama sekali. Semua kerumitan ini bersifat global, dan jangan nafikan bahwa ini berkaitan dengan operasi intelijen. Intelijen itu bisa asing dan bisa juga lokal.

Para pelaku teror akhirnya menjadi jelas hanya sebagai pion belaka. Ada yang memeliharanya. Mereka diciptakan, untuk pada suatu ketika yang dianggap tepat untuk diperangi sendiri sesuai kepentingan pememeliharaan kepentingan. Auditlah kerugian kemanusiaan dengan perspektif itu. Tentu Anda akan berkata betapa siasianya lilin-lilin yang dibakar oleh mobilisasi-mobilisasi sistematis yang pesan akhirnya pun menyisakan kekeruhan. Ucapan-ucapan gagap yang diviralkan pun, seperti "kami tak takut teror", "Kami mendukung Kepolisian”, akhirnya terasa menjadi upaya menyembunyikan akar masalah sesungguhnya.

Rizal Ramli (2017) dalam dialog dengan sebuah televisi swasta bersama Salim Said dengan tema "Ekonomi Dalam Bingkai Pancasila" begitu tegas mengatakan bahwa radikalisme atau semacamnya tidak perlu dikhawatirkan di sebuah negara yang rakyatnya sejahtera. Inilah agenda yang ditelantarkan dari satu ke lain rezim, dengan catatan kegagapan dalam memilih strategi dan model pembangunan yang terlalu kanan (neoliberalis).

Penulis dosen FISIP UMSU. Koordinator Umum Pengembangan Basis Sosial Inisiatif \& Swadaya ("nBASIS). 